\title{
The Impact of Immediate and Delayed Written Pushed Output Produced by Pre-intermediate EFL Learners in Iran on Their Acquisition of English Verb Tenses
}

\author{
Parviz Birjandi \\ Department of English language Teaching, Science and Research Branch, Islamic Azad University, Tehran, Iran \\ Homa Jafarpour Mamaghani \\ Department of English language Teaching, Science and Research Branch, Islamic Azad University, Tehran, Iran
}

\begin{abstract}
The present study aimed at investigating the impact of immediate and delayed written Pushed Output on the acquisition of English verb tenses. To this end, 32 freshmen majoring in English translation were selected as the participants of the study. After they were randomly assigned to three groups, i.e. two experimental groups Immediate Written Pushed Output (IWPO) group and Delayed Written Pushed Output (DWPO) group and a control group (CG), a pre-test was administered. Then for eight sessions all three groups received explicit instructions on English verb tenses. Subsequently, the experimental group was assigned to perform some output tasks whereas the control group was given conventional multiple choice tests instead. The EG1 (DWPO) had a 10-minute planning time before performing the tasks, while EG2 (IWPO) had to perform the tasks as soon as they received them. Every week the participants in all three groups received feedback on their performances. Following the treatment sessions, a post- test was run. Finally, the comparison of the three groups' performances on the posttest as well as the comparison of each group's performance on the pretest and posttest supported the facilitative effects of both delayed and immediate written pushed output on the acquisition of English verb tenses.
\end{abstract}

Index Terms - avoidance strategy, interlanguage development, output hypothesis, pushed output

\section{INTRODUCTION}

The current perspectives on second language acquisition (SLA) underscore the importance of the target language output produced by language learners in the process of SLA. It is believed that for instructed second language learning the presence of comprehensible input along with active production of linguistic output is indispensible. In other words, for successful SLA, exposure to input is an efficient but not sufficient element specifically for the development of grammatical accuracy.

Unlike Krashen $(1982,1985)$ who considers comprehensible input as the only factor leading to the acquisition of language and the development of grammatical accuracy, some scholars as Mackey and Oliver (2002); Mackey, Oliver and Leeman (2003); Mackey and Philp, (1998); McDonough (2005); Skehan (1998); and Swain (1985, 1991, 1993, 1995, 1998, 2000, 2001, and 2005) put greater emphasis on target language output produced by language learners.

Swain's (1985) studies of French immersion programs in Canada, which led to her output Hypothesis, reveal that in the settings where L2 learners are exposed to continuous and huge amount of target language input, they may ultimately reach native like comprehension and fluency in the target language, and speak fluently; nevertheless, "their productive skills remain far from native like, particularly with respect to grammatical competence" (Swain, 1991, p. 98). Swain attributes this to the lack of learner "output" in immersion programs. Swain (1995) hypothesizes that learners in immersion situations are not "pushed" to analyze the grammar of the target language because they can communicate their message without such a task. Swain's Output Hypothesis (1985, 1993, 1995, and 2005) holds that "the act of producing language (speaking or writing) constitutes, under certain circumstances, part of the process of second language learning" (Swain, 2005, p. 471). She contends that "output may stimulate learners to move from the semantic, open-ended nondeterministic, strategic processing prevalent in comprehension to the complete grammatical processing needed for accurate production" (Swain, 1995, p. 128). On the basis of Output Hypothesis, language production gives second language learners the opportunity to modify their performances and produce comprehensible output; it also prompts learners to stretch their existing interlanguage capacity to fill the gap in their existing interlanguage, that is to say the gap between what they want to say and what they can say. Swain believes that when learners are pushed to produce language, they are actually forced to think about syntax. According to Swain (1985), the role of output is "to provide opportunities for contextualized, meaningful use, to test out hypothesis about the target language, and to move 
the learner form a purely semantic analysis of the language to a syntactic analysis of it" (p. 252). Swain further reiterates that this processing promotes more linguistic accuracy.

The effects of output on SLA have been investigated quite widely. The studies conducted in the realm of output hypothesis have mostly concentrated on the potential functions of pushed output in SLA including noticing (Schmidt, 1990; Schmidt \& Frota, 1986; Swain, 1995), hypothesis testing (Swain, 1995), automaticity (Anderson, 1982; DeKeyser, 1997; McLaughlin, 1987), grammatical monitoring (Izumi, 2003), and stimulating syntactic processing (de Bot, 1996).Other studies undertaken by SLA scholars including Mackey and Philp (1998), Mackey and Oliver (2002) Mackey, Oliver, and Leeman (2003), and McDonough (2005), yielded support to Swain's idea concerning the positive impact of pushed output on the acquisition of grammatical forms, nevertheless it may not be the mere production of output that affects the process of SLA. The channel features of the pushed output, the amount of planning time available before output production, the task types employed for output elicitation and many other factors may also impact the development of learners' interlanguage towards the target language norms.

The myriad Output studies undertaken in the realm of ELT have examined the effect of L2 learners' output on their L2 proficiency with regard to the accuracy, complexity, fluency. Some other studies consider the impacts of different intervening variables including proficiency level, task type, planning time, and the context of production. However, the focus of the present study is exclusively on the effects of Immediate and Delayed Written Pushed Output on the development of Iranian ESL learners' interlanguage in terms of verb tenses. To this end, the researcher addressed the following questions:

1. Does Immediate Written Pushed Output (IWPO) enhance the acquisition of English verb tenses?

2. Does Delayed Written Pushed Output (DWPO) enhance the acquisition of English verb tenses?

3. Does the provision of planning time before performing the output tasks enhance the acquisition of English verb tenses?

\section{METHOD}

\section{A. Participants}

To achieve the objectives of the present study 32 students were selected from among 50 freshmen of Islamic Azad University of Karaj, Iran, majoring in English translation as the participants of the study. The selection was based on their scores on "Oxford Placement Test" (OPT) (Allan, 1992). The 32 participants were the ones whose scores fell within the range of pre- intermediate level.

\section{B. Instrumentation}

\section{Oxford Placement Test (OPT)}

The first instrument used in the course of this study was OPT which was implemented to determine the homogeneity of the participants concerning their English language proficiency. The estimated reliability for the OPT was .87 which is reported in table one.

TABLE 1.

THE ESTIMATED RELIABILITY FOR THE OPT

\begin{tabular}{|l|l|l|l|l|}
\hline & THE ESTIMATED RELIABILITY FOR THE OPT & K-R21 \\
\hline OPT & Mean & Variance & Items & .87 \\
\hline
\end{tabular}

\section{Pretest and posttest}

The pre-test and post-test implemented through the course of this study were two parallel grammar tests constructed by the researcher. The time considered for the completion of each test was 90 minutes. Due to their parallel nature, both tests enjoyed an identical structure, including grammaticality judgment, error correction, and Persian to English translation.

The grammaticality judgment and error correction parts of each test included 40 items, with 28 ungrammatical items each of which contained only one tense related mistake. The participants were required to put a tick mark next to the grammatically correct sentences, but underline the ungrammatical parts and write the correct form on top of the erroneous parts. The translation section of each test included a dialog in the participants' L1 the translation of which into English entailed the use of the instructed verb tenses. In the construction of this section of the tests the outmost caution was exercised to minimize lexical difficulty, and when necessary, the needed lexical items were provided to eliminate possible sources of distraction or anxiety.

The content and item characteristics of the tests were scrupulously checked and compered by the researcher and two other colleagues to make sure that the tests were parallel. Moreover, the Pearson correlations between the OPT and the pretest and posttest of verb tenses were run to probe the empirical validity of the latter tests. Based on the results displayed in Table two it was concluded that both pretest $(\mathrm{R}=.65, \mathrm{P}<.05)$ and Posttest $(\mathrm{R}=.68, \mathrm{P}<.05)$ enjoy a significant degree of validity. 
TABLE 2:

PEARSON CORRELATIONS OPT WITH PRETEST AND POSTTEST OF VERB TENSES

\begin{tabular}{|c|c|c|}
\hline & & OPT \\
\hline \multirow{3}{*}{ Pretest } & Pearson Correlation & $.652^{* *}$ \\
\hline & Sig. (2-tailed) & .000 \\
\hline & $\mathrm{N}$ & 32 \\
\hline \multirow{3}{*}{ Posttest } & Pearson Correlation & $.683^{* *}$ \\
\hline & Sig. (2-tailed) & .000 \\
\hline & $\mathrm{N}$ & 32 \\
\hline
\end{tabular}

The pretest and posttest were run prior to the treatment, and one week after the last treatment successively.

The participants' responses to the translation, error identification and error correction items were scored through subtracting the number of the incorrect use, identification or correction of each tense-related structure from the total number of the obligatory contexts for those structures. 1 point for each correct and 0 point for each incorrect use, identification or correction was assigned.

\section{Output tasks}

Ortega (1999, p. 112) summarizes different types of tasks which can be used for elicitation of output as "storyretelling, picture description, decision-making, personal information exchange, giving instructions, giving directions, telephone answering-machine messages, summary of conversation, general discussion questions, and academic lecturettes". In this study the researcher implemented structured picture description and Persian to English translation tasks the completion of which entails the intended grammatical structures.

The picture narrative tasks were implemented on the ground that they have been frequently used in output studies (Foster \& Skehan, 1996; Shehadeh, 2003; Tavakoli \& Skehan, 2005; Gilabert, 2007; Khatib \& Bagherkazemi, 2011). Moreover, according to Tavakoli \& Skehan (2005), "using narratives is justified in terms of construct validity, reliability and authenticity of the test" (p. 249).

The use of translation tasks, on the other hand, is also justified by their use in output studies (Macaro \& Masterman, 2006; Kobayashi \& Rinnert, 1992) and their potential ability in preventing language learners from using avoidance strategy. As put by Kormos (2006), when language learners struggle to produce target language that is above their level of proficiency, they may turn to avoidance strategies like message abandonment, message reduction, and message replacement. Kormos (2006) explains that using these strategies "does not actually solve the original problem but rather helps the speaker get over the problem situation and thus avoid a complete communication breakdown" (p. 141). Thus, the researcher decided to employ translation tasks to preclude any possible avoidance based variation in the output of the participants.

In selecting every session's tasks, due caution was exercised to make certain that the needed tense for the completion of the tasks had been instructed. Translation tasks had the same features as the translation section of the pre and posttests. It should be noted that to examine the tasks in terms of length and difficulty a pilot study was carried out and the needed modifications were incorporated to adjust them to the proficiency level of the participants.

\section{Target Forms}

The grammatical forms targeted in the present study were English verb tenses. The choice of verb forms was due to the observed grammatical incompetency of EFL learners specifically in the accurate use of verb tenses evidenced in their oral and written output. The importance of the tense-aspect acquisition is also reiterated by other authors such as Shirai, and Kuruno (1998). Asserting the importance of the acquisition of tense and aspect, Shirai and Kuruno point out that "from a functional viewpoint, tense-aspect is an important communicative device to establish time reference as well as to express how the speaker views the temporal contour of a situation" (p. 246). Moreover, as Bardovi-Harlig (2000) mentions, the acquisition of tense and aspect systems has been emphasized in several descriptive and pedagogical accounts of language and has always been an important part of the curricula of many language programs.

\section{PROCEDURES}

This study was conducted during a whole semester on 32 participants at pre- intermediate level of proficiency who were selected from among fifty freshmen on the basis of their marks on OPT (Allan 1992). The 32 participants were then assigned to three homogeneous groups, namely IWPO, DWPO, and Control on random bases. A week later they were given a pre-test to determine their entry behavior regarding their knowledge of English verb tenses. Over the following eight weeks, all three groups received explicit grammar instructions along with sentence level practice exercises. After the instruction, every session the members of the two experimental groups received some output tasks. Meanwhile, the members of the control group were required to do a conventional multiple choice test covering the newly presented structures. However, the members of (IWPO) group were assigned to start the tasks immediately after receiving them. The same procedure was used with (DWPO) group, but they were given a 10 - minute planning time before they did the output tasks. Finally every session the learners' papers were corrected and the participants of all three groups received explicit teacher feedback together with conference feedback on their performances on the tasks and tests the next week. After eight weeks of treatment, a post -test was run to check the effectiveness of the treatments. 


\section{DATA ANALYSis}

Incorporating a pretest and post-test design, the present study was undertaken to test the following two null hypotheses:

H01: Immediate Written Pushed Output (IWPO) does not enhance the acquisition of English verb tenses.

H02: Delayed Written Pushed Output (IWPO) does not enhance the acquisition of English verb tenses.

H03: The provision of planning time before performing the output tasks does not enhance the acquisition of English verb tenses.

Statistically, the assumption behind the null hypotheses is that there are no significant differences between the experimental groups' mean scores on the pretest and posttest. In order to compare the experimental groups' performance on the pretest and posttest a repeated measures ANOVA was run, using the 16th version of the Statistical Package for Social Sciences (SPSS), setting the level of significance at 0.05. It should be mentioned that before running the ANOVA necessary caution was exercised to make sure that the main assumptions of repeated measure ANOVA, were met. The present data (OPT, Pretest, Posttest) are measured on an interval scale. The assumption of independence was also met since none of the subjects participated in more than one group. The result of normality check measured through the ratios of skewness and kurtosis over their respective standard errors is displayed in Table three. The ratios of skewness and kurtosis over their standard errors were all within the ranges of plus and minus 1.96 (Field; 2009 ). Based on these results, it was concluded that the present data enjoyed normal distributions.

TABLE 3:

NORMALITY TESTS

\begin{tabular}{|c|c|c|c|c|c|c|c|c|}
\hline \multirow[t]{2}{*}{ Group } & & \multirow{2}{*}{\begin{tabular}{|l}
$\mathrm{N}$ \\
Statistic
\end{tabular}} & \multicolumn{3}{|l|}{ Skewness } & \multicolumn{3}{|l|}{ Kurtosis } \\
\hline & & & Statistic & Std. Error & Ratio & Statistic & Std. Error & Ratio \\
\hline \multirow{3}{*}{ DWPO } & OPT & 10 & -.355 & .687 & -0.517 & -1.609 & 1.334 & -1.206 \\
\hline & Pretest & 10 & -.326 & .687 & -0.475 & -1.351 & 1.334 & -1.013 \\
\hline & Posttest & 10 & -.292 & .687 & -0.425 & -1.261 & 1.334 & -0.945 \\
\hline \multirow{3}{*}{ IWPO } & OPT & 12 & .153 & .637 & 0.240 & -1.308 & 1.232 & -1.062 \\
\hline & Pretest & 12 & -.167 & .637 & -0.262 & -1.208 & 1.232 & -0.981 \\
\hline & Posttest & 12 & -.199 & .637 & -0.312 & -1.038 & 1.232 & -0.843 \\
\hline \multirow{3}{*}{ Control } & OPT & 10 & .261 & 687 & 0.380 & -1.909 & 1.334 & -1.431 \\
\hline & Pretest & 10 & -.790 & .687 & -1.150 & -.205 & 1.334 & -0.154 \\
\hline & Posttest & 10 & -.790 & .687 & -1.150 & -.205 & 1.334 & -0.154 \\
\hline
\end{tabular}

$I W P O=$ Immediate written pushed output and DWPO = Delayed written pushed output

The assumption of homogeneity of variances will be discussed when reporting the results of the one-way ANOVA.

\section{A. Homogeneity of the Participants}

As was mentioned, to select homogeneous groups of the participants, OPT was run and the ones within the range of pre- intermediate were selected as the participants of the study. Moreover, the OPT marks of the selected group were compared. As the results indicate in table four, there were not any significant differences between the mean scores of the groups on OPT $\left(\mathrm{F}(2,29)=1.76, \mathrm{p}>.05, \omega^{2}=.04\right)$. The results represent a weak to moderate effect size. Therefore, the groups enjoyed the same levels of general language proficiency prior to the main study.

TABLE 4:

ONE-WAY ANOVA OPT BY GROUPS

\begin{tabular}{|l|l|l|l|l|l|l|}
\hline \multicolumn{2}{|c|}{} & Sum of Squares & df & Mean Square & F & Sig. \\
\hline \multirow{3}{*}{ OPT } & Between Groups & 48.969 & 2 & 24.484 & 1.764 & .189 \\
\cline { 2 - 7 } & Within Groups & 402.500 & 29 & 13.879 & & \\
\cline { 2 - 7 } & Total & 451.469 & 31 & & & \\
\hline
\end{tabular}

The descriptive statistics for OPT were tabularized in table number five

TABLE 5:

DESCRIPTIVE STATISTICS OPT BY GROUPS

\begin{tabular}{|c|c|c|c|c|c|c|c|c|c|}
\hline & & \multirow{2}{*}{$\mathrm{N}$} & \multirow{2}{*}{ Mean } & \multirow{2}{*}{$\begin{array}{l}\text { Std. } \\
\text { Deviation }\end{array}$} & \multirow{2}{*}{ Std. Error } & \multicolumn{2}{|c|}{ 95\% Confidence Interval for Mean } & \multirow{2}{*}{ Minimum } & \multirow{2}{*}{ Maximum } \\
\hline & & & & & & Lower Bound & Upper Bound & & \\
\hline \multirow{4}{*}{ OPT } & DWPO & 10 & 56.900 & 4.5080 & 1.4256 & 53.675 & 60.125 & 50.0 & 62.0 \\
\hline & IWPO & 12 & 55.000 & 3.1042 & .8961 & 53.028 & 56.972 & 50.0 & 59.0 \\
\hline & Control & 10 & 53.800 & 3.5528 & 1.1235 & 51.258 & 56.342 & 50.0 & 59.0 \\
\hline & Total & 32 & 55.219 & 3.8162 & .6746 & 53.843 & 56.595 & 50.0 & 62.0 \\
\hline
\end{tabular}

It should be noted that the assumption of homogeneity of variances is met on OPT (Levene' $\mathrm{F}(2,29)=2.03, \mathrm{P}>.05)$.

TABLE 6:

HOMOGENEITY OF VARIANCES OPT BY GROUPS

\begin{tabular}{|l|l|l|l|l|}
\hline & Levene Statistic & df1 & df2 & Sig. \\
\hline OPT & 2.035 & 2 & 29 & .149 \\
\hline
\end{tabular}




\section{B. Pretest}

A week after the selection of the participants of the study a pre-test was administered to determine their entry knowledge of English verb tenses. Later a One-Way ANOVA was run to compare the three groups pretests the results of which indicated no significant differences between the mean scores of the groups on pretest of verb tenses $(\mathrm{F}(2,29)$ $\left.=1.14, \mathrm{p}>.05, \omega^{2}=.009\right)$. The result does represent a weak effect size. Therefore, the groups enjoyed the same levels of knowledge on verb tenses prior to the main study. Tables seven, eight, and nine summarize the results of the OneWay ANOVA of the pretest by groups, the descriptive statistics of the pretest by groups, and homogeneity of variances of the pretest by groups respectively.

TABLE 7:

ONE-WAY ANOVA PRETEST OF VERB TENSES BY GROUPS

\begin{tabular}{|l|l|l|l|l|l|l|}
\hline \multicolumn{2}{|l|}{} & Sum of Squares & df & Mean Square & F & Sig. \\
\hline \multirow{3}{*}{ Pretest } & Between Groups & 52.583 & 2 & 26.292 & 1.142 & .333 \\
\cline { 2 - 8 } & Within Groups & 667.417 & 29 & 23.014 & & \\
\cline { 2 - 8 } & Total & 720.000 & 31 & & & \\
\hline
\end{tabular}

TABLE 8:

DESCRIPTIVE STATISTICS PRETEST OF VERB TENSES By GROUPS

\begin{tabular}{|c|c|c|c|c|c|c|c|c|c|}
\hline & & \multirow{2}{*}{$\mathrm{N}$} & \multirow{2}{*}{ Mean } & \multirow{2}{*}{$\begin{array}{l}\text { Std. } \\
\text { Deviation }\end{array}$} & \multirow{2}{*}{ Std. Error } & \multicolumn{2}{|c|}{$\begin{array}{l}95 \% \text { Confidence Interval } \\
\text { for Mean }\end{array}$} & \multirow{2}{*}{ Minimum } & \multirow{2}{*}{ Maximum } \\
\hline & & & & & & $\begin{array}{l}\text { Lower } \\
\text { Bound }\end{array}$ & $\begin{array}{l}\text { Upper } \\
\text { Bound }\end{array}$ & & \\
\hline \multirow{4}{*}{ Pretest } & DWPO & 10 & 49.600 & 3.8355 & 1.2129 & 46.856 & 52.344 & 44.0 & 55.0 \\
\hline & IWPO & 12 & 52.417 & 4.6213 & 1.3340 & 49.480 & 55.353 & 45.0 & 59.0 \\
\hline & Control & 10 & 52.300 & 5.7745 & 1.8260 & 48.169 & 56.431 & 41.0 & 59.0 \\
\hline & Total & 32 & 51.500 & 4.8193 & .8519 & 49.762 & 53.238 & 41.0 & 59.0 \\
\hline
\end{tabular}

It should be noted that the assumption of homogeneity of variances was met on the Pretest (Levene' F $(2,29)=1.33$, $\mathrm{P}>$.05).

TABLE 9:

HOMOGENEITY OF VARIANCES PRETEST OF VERB TENSES By GROUPS

\begin{tabular}{|l|l|l|l|l|}
\hline & Levene Statistic & df1 & df2 & Sig. \\
\hline Pretest & 1.337 & 2 & 29 & .278 \\
\hline
\end{tabular}

\section{Answers to the Research Questions}

The analysis of the data gathered in the course of the study indicated that there were significant differences between the mean scores of the groups on posttest of verb tenses $\left(\mathrm{F}(2,29)=12.09, \mathrm{p}<.05, \omega^{2}=.49\right.$ it does represent a large effect size).

TABLE 10:

ONE-WAY ANOVA POSTTEST OF VERB TENSES BY GROUPS

\begin{tabular}{|l|l|l|l|l|l|l|}
\hline \multicolumn{2}{|c|}{} & Sum of Squares & df & Mean Square & F & Sig. \\
\hline \multirow{3}{*}{ Posttest } & Between Groups & 701.952 & 2 & 350.976 & 12.095 & .000 \\
\cline { 2 - 7 } & Within Groups & 841.517 & 29 & 29.018 & & \\
\cline { 2 - 7 } & Total & 1543.469 & 31 & & & \\
\end{tabular}

Table 11 displays the descriptive statistics for posttest of verb tenses.

TABLE 11:

DESCRIPTIVE STATISTICS POSTTEST OF VERB TENSES By GROUPS

\begin{tabular}{|c|c|c|c|c|c|c|c|c|c|}
\hline & & \multirow{2}{*}{$\mathrm{N}$} & \multirow{2}{*}{ Mean } & \multirow{2}{*}{$\begin{array}{l}\text { Std. } \\
\text { Deviation }\end{array}$} & \multirow{2}{*}{ Std. Error } & \multicolumn{2}{|c|}{$\begin{array}{l}\text { 95\% Confidence } \\
\text { Interval for Mean }\end{array}$} & \multirow{2}{*}{ Minimum } & \multirow{2}{*}{ Maximum } \\
\hline & & & & & & $\begin{array}{l}\text { Lower } \\
\text { Bound }\end{array}$ & $\begin{array}{l}\text { Upper } \\
\text { Bound }\end{array}$ & & \\
\hline \multirow{4}{*}{ Posttest } & DWPO & 10 & 61.500 & 4.5277 & 1.4318 & 58.261 & 64.739 & 55.0 & 68.0 \\
\hline & IWPO & 12 & 65.583 & 5.6962 & 1.6444 & 61.964 & 69.203 & 56.0 & 74.0 \\
\hline & Control & 10 & 54.300 & 5.7745 & 1.8260 & 50.169 & 58.431 & 43.0 & 61.0 \\
\hline & Total & 32 & 60.781 & 7.0562 & 1.2474 & 58.237 & 63.325 & 43.0 & 74.0 \\
\hline
\end{tabular}

Although the F-value of 5.89 indicates significant differences between the means of the groups, the post-hoc Scheffe's tests was run to compare them two by two.

Based on the results displayed in Table 10 it was concluded that:

A: The Immediate Written Pushed Output (IWPO) outperformed the control group on the posttest of English verb tenses $(\mathrm{MD}=11.28, \mathrm{P}<.05)$. Thus the first null-hypothesis was rejected.

B: The Delayed Written Pushed Output (DWPO) outperformed the control group on the posttest of English verb tenses $(\mathrm{MD}=7.20, \mathrm{P}<.05)$. Thus the second null-hypothesis was rejected. 
C: There was not any significant difference between the Immediate and Delayed Pushed Outputs on the posttest of verb tenses $(\mathrm{MD}=4.08, \mathrm{P}>.05)$. Thus the third null-hypothesis was not rejected.

TABLE 12:

POST-HOC SCHEFFE's TESTS

\begin{tabular}{|c|c|c|c|c|c|c|}
\hline \multirow[t]{2}{*}{ (I) Group } & \multirow[t]{2}{*}{ (J) Group } & \multirow[t]{2}{*}{ Mean Difference (I-J) } & \multirow[t]{2}{*}{ Std. Error } & \multirow[t]{2}{*}{ Sig. } & \multicolumn{2}{|c|}{$95 \%$ Confidence Interval } \\
\hline & & & & & Lower Bound & Upper Bound \\
\hline \multirow{2}{*}{ DWPO } & Control & $7.2000^{*}$ & 2.4091 & .020 & .985 & 13.415 \\
\hline & IWPO & 4.0833 & 2.3065 & .226 & -1.867 & 10.034 \\
\hline IWPO & Control & $11.2833^{*}$ & 2.3065 & .000 & 5.333 & 17.234 \\
\hline
\end{tabular}

It should be noted that the assumption of homogeneity of variances is met on Pretest (Levene' F $(2,29)=.598$, $\mathrm{P}>$.05).

TABLE 13:

HOMOGENEITY OF VARIANCES POSTTEST OF VERB TENSES BY GROUPS

\begin{tabular}{|l|l|l|l|l|}
\hline & Levene Statistic & df1 & df2 & Sig. \\
\hline Posttest & .598 & 2 & 29 & .557 \\
\hline
\end{tabular}

\section{DISCUSSION}

Generally, this study addressed the effects of written pushed output tasks with and without pre task planning time on EFL learners' acquisition of English verb tenses. Based on the results of the data analysis, it can be mentioned that language learners' Written Pushed Output, both with and without planning time, used as a means of practice can have positive effects on EFL learners' acquisition of English verb tenses.

The first research questions investigated the effect of IWPO, used as a means to practice the newly presented grammatical forms, on the acquisition of English verb tenses. The analysis of the data indicated that the IWPO group outperformed the control group on the posttest of English verb tenses $(\mathrm{MD}=11.28, \mathrm{P}<.05)$. On the basis of this result, it can be concluded that pushing learners to put their newly gained knowledge of form into use while performing meaningful and contextualized written output tasks, even under the pressure of time, can contribute to directing EFL learners' attention to language form and in turn lead to the acquisition of language form and higher degree of accuracy. This finding is consistent with the finding of Yuan \& Ellis (2003) who believe that on-line planning is a useful methodological operation through which accuracy develops.

The Second research question addressed the effect of DWPO on the acquisition of English verb tenses. As the results of the date analysis indicated, the DWPO group outperformed the control group on the posttest of English verb tenses $(\mathrm{MD}=7.20, \mathrm{P}<.05)$ which reveals that output produced from written channel and with planning time can have similar positive effect on the development of grammatical accuracy and more specifically on the accurate use of English verb tenses. This finding is in line with the findings of scholars like Foster and Skehan, 1996; Mehnert, 1998; Skehan and Foster, 1997. On the other hand, studies conducted by some other scholars like Crookes, 1989; Ortega, 1999, and Wigglesworth, 1997 do not support the finding of this study.

It should be noted that these studies were mostly product-oriented and investigated the effects of planning time on the immediate linguistic output of their participants, whereas the present study investigated longer effects of planning time on the accuracy of EFL learners, i.e., in this study planning time was provided during the treatment sessions and not before the post and delayed posttests.

The third research question concerned the effect of pre-task planning time before performing output tasks on the acquisition of English verb tenses. Statistically, the assumption behind the third null hypothesis is that there are no significant differences between the IWPO and DWPO groups' mean scores on the pretest and posttest. The result of the data analysis indicated no significant difference between the scores of the two groups on the posttest $(\mathrm{MD}=4.08$, $\mathrm{P}>$.05), and accordingly the third null-hypothesis was not rejected while it was supposed that pre task planning time could give the participants the chance to summon their meta- linguistic knowledge. The results of this study are not in line with the ideas of scholars like Skehan (1996) who contend that when learners are deprived from pre-task planning time and they are pushed to on- line communication, they may resort to communicative strategies and lexicalized language production, that is, they may attend merely to meaning and disregard the form and this in turn may lead to fossilization of learners' interlanguage mistakes. This unexpected result might be due to the fact that unlike most of the one-shot output studies which investigate the effects of provision of planning time on L2 accuracy, complexity or fluency, this study considered the effects of planning time from another perspective. Here what was investigated was not the effect of these two variables on the accuracy in a single specific output task but on the development of the participants' accuracy in the course of continual experience of being pushed to produce L2 output with and without planning time. These findings might be attributable to individual learner differences, i.e., learners' affective variables. Therefore, a larger sample size might have yielded different results.

\section{CONCLUSIONS AND IMPLICATIONS}


The present study was inspired by Swain's Output Hypothesis and investigated the effects of Immediate and Delayed Written Pushed Output on the acquisition of English verb tenses by Iranian EFL learners. The results of this study, supporting Swain's Output Hypothesis and the findings of other scholars as Mackey and Philp (1998), Mackey and Oliver (2002) Mackey, Oliver, and Leeman (2003), and McDonough (2005), confirm the positive effects of providing language learners with output opportunities, as a means of practice, on the acquisition of language forms. This study with its focus on the written channel of learner output indicated that written output, regardless of temporal features of its production, can have beneficial effect on the development of grammatical accuracy. Nevertheless, here a word of caution is in order. This study suffers from some limitations including the small number of the participants of the study, and limited period of data collection (ten 90-minut-sessions). A longer period of data collection may lead to better description of changes in learners' interlanguage.

The findings of the present study may have theoretical and pedagogical advantages in the field of ELT. Theoretically, they may add to the body of knowledge concerning the impact of pushed output, from written channel of production and under two different temporal conditions, on the process and quality of SLA. Moreover, in the present study the findings of previous output studies which are mainly based on research conducted in European milieu are tested in a non-European environment, Iran. Besides, pedagogically, it might provide ELT Curriculum designers and practitioners with useful information for designing and/or adopting ELT curricula, tasks and activities.

Note: The List of Abbreviations

OPT = Oxford Placement Test

IWPO= Immediate Written Pushed Output

DWPO=Delayed Written Pushed Output

$\mathrm{EG}=$ Experimental Group

$\mathrm{CG}=$ Control Group

\section{REFERENCES}

[1] Allan, D. (1992). Oxford placement test. Oxford: Oxford University Press.

[2] Anderson, J. R. (1982). Acquisition of cognitive skill. Psychological Review 89, 369- 406.

[3] Bardovi-Harlig, K. (2000). Tense and aspect in second language acquisition: Form, meaning, and use. Malden, MA: Blackwell.

[4] Crookes, G. (1989). Planning and interlanguage variation. Studies in Second Language Acquisition 11, 367-383.

[5] de Bot, K. (1996). The psycholinguistics of the output hypothesis. Language Learning 46,529-555.

[6] DeKeyser, R. (1997). Beyond explicit rule learning: Automatizing second language morphosyntax. Studies in Second Language Acquisition 19, 195-221.

[7] Field, A. (2009). Discovering statistics using SPSS (3rd ed.). London: Sage Publications, Inc.

[8] Foster, P., \& Skehan, P. (1996). The influence of planning and task type on second language performance. Studies in Second Language Acquisition 18, 299-323.

[9] Gilabert, R. (2007). The simultaneous manipulation of task complexity along planning time and [+/-Here-and-Now]: Effects on L2 oral production. In M. P. Garcia-Mayo (Ed.), Investigating tasks in formal language learning. Clevedon: Multilingual Matters, 44- 68.

[10] Izumi, S. (2003). Comprehension and production processes in second language learning: In search of the psycholinguistic rationale of the Output Hypothesis. Applied Linguistics 24.2, 168-196.

[11] Khatib, M., \& Bagherkazemi, M. (2011). The potential of learner output for enhancing EFL Learners' short-term and long-term learning of the English simple present tense. Theory and Practice in Language Studies 1.4, 400- 407.

[12] Kobayashi, H. \& Rinnert, C. (1992). Effects of first language on second language writing. Translation versis direct composition. Language Leaning 142, 183- 215.

[13] Kormos, J. (2006). Speech production and second language acquisition. Mahwah, N.J.: Lawrence Erlbaum Associates.

[14] Krashen, S.D. (1982). Principles and practice in second language acquisition. Oxford: Oxford University Press.

[15] Krashen, S. (1985). The Input hypothesis: Issues and implications. New York: Longman.

[16] Macaro, E., \& Masterman, L. (2006). Does intensive explicit grammar instruction make all the difference? Language Teaching Research 10.3, 297-327.

[17] Mackey, A., \& Oliver, R. (2002). Interactional feedback and children's L2 development. System 30, 459-477.

[18] Mackey, A., Oliver, R., \& Leeman, J. (2003). Interactional input and the incorporation of feedback: An exploration of NSNNS and NNS-NNS adult and child dyads. Language Learning 53, 35- 66.

[19] Mackey, A., \& Philp, J. (1998). Conversational interaction and second language development: Recasts, responses and red herrings? The Modern Language Journal 82, 338- 356.

[20] McDonough, K. (2005). Identifying the impact of negative feedback and learner's responses on ESL question development. Studies in Second Language Acquisition 27, 79- 103.

[21] McLaughlin, B. (1987). Theories of second language learning. New York: Edward Arnold.

[22] Mehnert, U. (1998). The effects of different lengths of time for planning on second language performance. Studies in Second Language Acquisition 20, 52- 83.

[23] Ortega, L. (1999). Planning and focus on form in L2 oral performance. Studies in Second Language Acquisition 21, $109-148$.

[24] Schmidt, R. (1990). The role of consciousness in second language learning. Applied Linguistics 11, 129-158.

[25] Schmidt, R., \& Frota, S. (1986). Developing basic conversational ability in a second language: A case study of an adult learner of Portuguese. In R. R. Day (Ed.), Talking to learn: Conversation in second language acquisition. Cambridge: Newbury House, 237- 326.

[26] Shehadeh, A. (2003). Learner output, hypothesis testing, and internalizing linguistic knowledge. System 31, $155-171$. 
[27] Shirai, Y. \& Kuruno, A. (1998). The acquisition of tense-aspect marking in Japanese as a second language. Language Learning 48.2, 245- 279 .

[28] Skehan, P. (1996). A framework for the implementation of task-based instruction. Applied Linguistics 17, 38- 62.

[29] Skehan, P. (1998). A cognitive approach to language learning. Oxford: Oxford University Press.

[30] Skehan, P., \& Foster, P. (1999). The influence of task structure and processing conditions on narrative retellings. Language Learning 49.1, 93- 120.

[31] Swain, M. (1985). Communicative competence: Some roles of comprehensible input and comprehensible output in its development. In S. Gass \& C. Madden (Eds.), Input in second language acquisition. Rowley: Newbury House, 235- 253.

[32] Swain, M. (1991). French immersion and its offshoots: Getting two for one. In B. Freed (Ed.), French language acquisition: Research and the classroom. Lexington, MA: Heath, 91- 103.

[33] Swain, M. (1993). The output hypothesis: Just speaking and writing aren't enough. The Canadian Modern Language Review 50, 158- 164

[34] Swain. M. (1995). Three functions of output in second language learning. In G. Cook, H. Widdowson \& B. Seidelhofer (Eds.), Principle \& practice in applied linguistics: Studies in honour of H.G. Widdowson. Oxford: Oxford University Press, $125-144$.

[35] Swain, M. (1998). Focus on form through conscious reflection. In C. Doughty \& J. Williams (Eds.), Focus on form in classroom second language acquisition. Cambridge: Cambridge University Press, 64-81.

[36] Swain, M. (2000).The output hypothesis and beyond: Mediating acquisition through collaborative dialogue. In J. Lantolf (Ed.), Sociocultural theory and second language learning. Oxford: Oxford University Press, 97- 114.

[37] Swain, M. (2001). Integrating language and content teaching through collaborative tasks. Canadian Modern Language Review 58.1, 44- 63 .

[38] Swain, M. (2005). The output hypothesis: Theory and research. In E. Hinkel (Ed.), Handbook of research in second language teaching and learning. London: Routledge, 471- 484.

[39] Tavakoli, P., \& Skehan, P. (2005). Strategic planning, task structure and performance testing. In R. Ellis (Ed.), Planning and task performance. Amsterdam: John Benjamins Publishing Company, 239- 273.

[40] Wigglesworth, G. (1997). An investigation of planning time and proficiency level on oral test discourse. Language Testing 14, 85- 106.

[41] Yuan F., \& Ellis, R. (2003). The effects of pre-task planning and on-line planning on fluency, complexity, and accuracy in L2 monologic oral production. Applied Linguistics 24.1, 1- 27.

Parviz Birjandi is a full professor holding an M.A. in Applied Linguistics from the Colorado State University and a Ph.D. in English Education from the University of Colorado, Boulder. He has published over 30 articles in TEFL. Moreover, he is the author of high school and several university textbooks. His major interests concern assessment, research methodology, and first language acquisition.

Homa Jafarpour Mamaghani is a lecturer holding an M.A. in English Education from Islamic Azad University, central branch, Tehran, Iran and a Ph.D. in English Education from Islamic Azad University, Science and Research branch, Tehran, Iran. She is currently teaching in Islamic Azad University, Karaj and Qazvin branches. Her research interests include second language acquisition, teacher education, and exploring the ways for implementing the principles of critical pedagogy in the context of foreign language learning. 